Psiquiatría y Salud Mental

Elsevier Editorial System(tm) for Revista de Manuscript Draft

Manuscript Number:

Title: Suicide in Castellon, 2009-2015: Do sociodemographic and psychiatric factors help understand urban-rural differences? Suicidio en Castellón entre 2009 y 2015: ¿Ayudan los factores sociodemográficos y psiquiátricos a entender las diferencias en suicidio entre ámbito urbano y rural?

Article Type: Original

Keywords: suicide; public health; sex differences; psychiatry; age. suicidio; salud pública; diferencias de sexo; psiquiatría; edad.

Corresponding Author: Dr. Carlos Suso-Ribera, Ph.D.

Corresponding Author's Institution: University Jaume I

First Author: Carlos Suso-Ribera, Ph.D.

Order of Authors: Carlos Suso-Ribera, Ph.D.; Rafael Mora-Marín, MD; Carmen Hernández-Gaspar, MD; Lidón Pardo-Guerra; María Pardo-Guerra, MD; Adela Belda-Martínez, MD; Ramón Palmer-Viciedo, PhD, MD

Abstract: Introduction. Studies have pointed to rurality as an important factor influencing suicide. Research so far suggests that several sociodemograpic and psychiatric factors might influence urban-rural differences in suicide. Also, their contribution appears to depend on sex and age. Unfortunately, studies including a comprehensive set of explanatory variables altogether are still scare and most studies have failed to present their analyses split by sex and age groups. Also, urban-rural differences in suicide in spain have been rarely investigated. The present study aimed at explaining rural-urban differences in suicidality in the province of XXXX (blinded) (Spain). A comprehensive set of sociodemographic and psychiatric factors was investigated and analyses were split by sex and age. Material and method. The sample comprised all suicides recorded in the province of XXXX (blinded) from January 2009 to December 2015 ( $\mathrm{n}=343$ ). Sociodemographic data included sex, age, and suicide method. Psychiatric data included the history of mental health service utilization, psychopathology, suicide attempts, and psychiatric hospitalization. Results. Consistent with past research, suicide rates were highest in rural areas, especially in men and older people. We also found that urban-rural differences in sociodemographic and psychiatric variables were sensitive to sex and age. Our results indicated that specialized mental health service use and accessibility to suicide means might help understand urban-rural differences in suicide, especially in men. When exploring urban-rural differences as a function of age, general practitioner visits for psychiatric reasons were more frequent in the older age group in rural areas. Conclusions. Study implications for suicide prevention strategies in Spain are discussed. 
Introducción. El nivel la ruralidad ha demostrado ser un factor importante en el suicidio. Las diferencias en suicidio según ruralidad parecen explicarse por factores sociodemográficos y psiquiátricos y su importancia depende del sexo y la edad. Hasta ahora, se han explorado pocos factores sociodemográficos y psiquiátricos a la vez, siendo aún más infrecuentes los análisis separando por sexo y edad. Además, en España, las diferencias en suicidio según ruralidad han sido poco investigadas. Este trabajo explora las diferencias en suicidio entre áreas rurales y urbanas en la provincia de XXXX (blinded) (España). Para ello, se evaluó un amplio conjunto de factores sociodemográficos (sexo, edad y método de suicidio) y psiquiátricos (historia de uso de servicios de salud mental, psicopatología, intentos de suicidio y hospitalización psiquiátrica). Los análisis se dividieron por sexo y edad. Material y método. La muestra incluyó todos los suicidios registrados en la provincia de XXXX (blinded) entre enero de 2009 y diciembre de 2015 ( $n=343$ ). Resultados. En línea con trabajos anteriores, encontramos tasas de suicidio más altas en las zonas rurales, especialmente en hombres y personas mayores. El efecto de las variables sociodemográficas y psiquiátricas sobre las diferencias en suicidio dependieron de sexo y edad. Así, el uso de salud mental y la accesibilidad a métodos de suicidio explicarían las diferencias de ruralidad en suicidio sobretodo en hombres, mientras que la frecuencia de visitas psiquiátricas con el médico de familia haría lo mismo en personas mayores. Conclusiones. En el texto se discuten las implicaciones de estos resultados para la prevención del suicidio en España.

Suggested Reviewers: 
Suicide in Castellon, 2009-2015: Do sociodemographic and psychiatric factors help understand urban-rural differences?

Suicidio en Castellón entre 2009 y 2015: ¿Ayudan los factores sociodemográficos y psiquiátricos a entender las diferencias en suicidio entre ámbito urbano y rural?

Short title: Urban-rural differences in suicide in Castellon

Short title: Diferencias en suicidio entre ámbito urbano y rural en Castellón

Suso-Ribera, Carlos $^{1} \mathrm{PhD}$; Mora-Marín, Rafael ${ }^{1,2}$, MD; Hernández-Gaspar, Carmen ${ }^{2}$, MD; Pardo-Guerra, Lidón ${ }^{4}$; Pardo-Guerra, María ${ }^{2}$, MD; Belda-Martínez, Adela ${ }^{3}$, MD; Palmer-Viciedo, Ramón ${ }^{2}, \mathrm{PhD}, \mathrm{MD}$.

${ }^{1}$ Department of Basic and Clinical Psychology and Psychobiology, University Jaume I, Spain

${ }^{2}$ Department of Psychiatry, Hospital Provincial of Castellón, Spain

${ }^{3}$ Department of Psychiatry, Mental Health Unit of Villa-Real, Spain

${ }^{4}$ Bonaire Mental Health and Geriatric Residence, Spain

Correspondence: Carlos Suso-Ribera. Tel:. 0034964387643 E-mail: susor@uji.es

\section{Aim and contributions}


The aim of the manuscript is to explore rural-urban differences in suicide in the province of Castellon (Spain) and to investigate social and psychiatric factors associated with such differences, while accounting for sex and age. We believe the manuscript has is has relevance for health. It is one of the first studies to explore urban-rural differences in suicide in Spain. Also, it includes a large set of factors that might contribute to urbanrural differences in suicide, which is rare (most studies include a few variables altogether). Finally, all analyses are performed separately for sex and age groups, so different explanations for urban-rural differences are offered as a function of sex and age.

\section{Declaration of Conflicting Interests}

The authors declare no potential conflicts of interest.

\section{Funding}

Elaboration of this work was partially supported by grant FHPCS 2016/04 from the Foundation of the Provincial Hospital of Castellon (Spain) and a grant from the College of Physicians in the province of Castellon.

\section{Acknowledgements}

We would like to thank the Institute of Forensic Medicine of Castellon for providing information on suicides in the province of Castellon and the Foundation of the Provincial Hospital of Castellon and the College of Physicians in the province of Castellon for their financial support. 


\section{Responsabilidades éticas}

Protección de personas y animales. Los autores declaran que para esta investigación no se han realizado experimentos en seres humanos ni en animales.

Confidencialidad de los datos. Los autores declaran que han seguido los protocolos de su centro de trabajo sobre la publicación de datos de pacientes.

Derecho a la privacidad y consentimiento informado. Los autores declaran que en este artículo no aparecen datos de pacientes. 


\section{Abstract}

Introduction. Studies have pointed to rurality as an important factor influencing suicide. Research so far suggests that several sociodemograpic and psychiatric factors might influence urban-rural differences in suicide. Also, their contribution appears to depend on sex and age. Unfortunately, studies including a comprehensive set of explanatory variables altogether are still scare and most studies have failed to present their analyses split by sex and age groups. Also, urban-rural differences in suicide in Spain have been rarely investigated. The present study aimed at explaining rural-urban differences in suicidality in the province of XXXX (blinded) (Spain). A comprehensive set of sociodemographic and psychiatric factors was investigated and analyses were split by sex and age. Material and method. The sample comprised all suicides recorded in the province of XXXX (blinded) from January 2009 to December 2015 ( $\mathrm{n}=$ 343). Sociodemographic data included sex, age, and suicide method. Psychiatric data included the history of mental health service utilization, psychopathology, suicide attempts, and psychiatric hospitalization. Results. Consistent with past research, suicide rates were highest in rural areas, especially in men and older people. We also found that urban-rural differences in sociodemographic and psychiatric variables were sensitive to sex and age. Our results indicated that specialized mental health service use and accessibility to suicide means might help understand urban-rural differences in suicide, especially in men. When exploring urban-rural differences as a function of age, general practitioner visits for psychiatric reasons were more frequent in the older age group in rural areas. Conclusions. Study implications for suicide prevention strategies in Spain are discussed.

Keywords: suicide; public health; sex differences; psychiatry; age. 
Introducción. El nivel la ruralidad ha demostrado ser un factor importante en el suicidio. Las diferencias en suicidio según ruralidad parecen explicarse por factores sociodemográficos y psiquiátricos y su importancia depende del sexo y la edad. Hasta ahora, se han explorado pocos factores sociodemográficos y psiquiátricos a la vez, siendo aún más infrecuentes los análisis separando por sexo y edad. Además, en España, las diferencias en suicidio según ruralidad han sido poco investigadas. Este trabajo explora las diferencias en suicidio entre áreas rurales y urbanas en la provincia de XXXX (blinded) (España). Para ello, se evaluó un amplio conjunto de factores sociodemográficos (sexo, edad y método de suicidio) y psiquiátricos (historia de uso de servicios de salud mental, psicopatología, intentos de suicidio y hospitalización psiquiátrica). Los análisis se dividieron por sexo y edad. Material y método. La muestra incluyó todos los suicidios registrados en la provincia de XXXX (blinded) entre enero de 2009 y diciembre de 2015 ( $\mathrm{n}=343$ ). Resultados. En línea con trabajos anteriores, encontramos tasas de suicidio más altas en las zonas rurales, especialmente en hombres y personas mayores. El efecto de las variables sociodemográficas y psiquiátricas sobre las diferencias en suicidio dependieron de sexo y edad. Así, el uso de salud mental y la accesibilidad a métodos de suicidio explicarían las diferencias de ruralidad en suicidio sobretodo en hombres, mientras que la frecuencia de visitas psiquiátricas con el médico de familia haría lo mismo en personas mayores. Conclusiones. En el texto se discuten las implicaciones de estos resultados para la prevención del suicidio en España.

Keywords: suicidio; salud pública; diferencias de sexo; psiquiatría; edad. 


\section{Introduction}

Suicide is a serious public health problem ${ }^{1,2}$. In 2012 suicide became the 15 th leading cause of death and accounted for $1.4 \%$ of all deaths worldwide ${ }^{3}$. In Spain, suicide was the first cause of unnatural death and the 11th leading cause of death in $2014^{4}$.

Research has pointed to rurality as an important factor explaining suicide. Higher suicide rates are frequently found in rural compared to urban areas and these differences have increased in the past decades ${ }^{5-8}$.

Several sociodemographic and psychiatric factors have been proposed to influence urban-rural differences in suicide. For example, urban-rural differences in suicide rates are largest among men ${ }^{5,6,9-11}$ and suicide risk for immigrants is highest in rural areas ${ }^{12}$. Also, while urban-rural differences in mental disorders appear to be negligible ${ }^{11,13,14}$, the use of mental health services is less frequent in rural areas ${ }^{11,15}$, suggesting accessibility problems (i.e., reduced number of specialists per capita or distance to health care facilities) or cultural differences (i.e., prejudice towards psychiatric treatment or asking for assistance) in rural areas.

Interestingly, research has also indicated that the influence of psychiatric and social factors on urban-rural differences in suicide is sensitive demographic characteristics, such as sex and age. For example, a higher accessibility to firearms and a lower proportion of general practitioner visits have been proposed to explain higher suicide rates rural areas, but only in males ${ }^{9,11}$. With regards to age, hanging has only been found to be more frequent in rural males aged 20-34 years, but not in older adults ${ }^{11}$.

Despite previous findings are promising, the extent to which sociodemographic and psychiatric factors might help understand urban-rural differences in suicide still needs more investigation. On the one hand, because sociodemographic and psychiatric 
variables are rarely explored altogether in the same study, arguably due to difficulties in gathering extensive clinical information in large-scale nation-wide studies. On the other, because research suggests that the effect of psychiatric and sociodemographic factors on urban-rural differences in suicide should be explored separately for men and women and across different ages, which is not a frequent practice.

The goal of the present study was twofold. First, we wanted to investigate whether rural-urban differences in suicidality in the province of $\mathrm{XXXX}$ (blinded) were comparable to those obtained in previous research. As reported in previous crossnational research ${ }^{16}$, results in countries other than Spain may not be generalizable to the Spanish population. Second, we aimed to explore whether urban-rural differences in sociodemographic and psychiatric factors helped understand urban-rural differences in suicide. In doing so, we will conduct separate analyses for males and females and across age groups. The focus on a smaller geographical area will facilitate the inclusion of several sociodemographic and psychiatric variables altogether.

\section{Material and Methods}

Sample and Procedure

The present study included all suicides recorded in XXXX (blinded) from January 2009 to December 2015. Sociodemographic data was provided by the Institute of Forensic Medicine of XXXX (blinded). This included name, sex, and age for all suicides, as well as date of suicide and suicide method.

From January 2009 to December 2015, 343 persons committed suicide in the province of XXXX (blinded). This information was obtained from the Institute of Forensic Medicine of XXXX (blinded) given existent discrepancies in the number of suicide 
cases when reported by the Spanish Statistical Office ${ }^{17}$. Of all suicides, $31(9.0 \%)$ did not appear in the centralized hospital database so they were excluded from further analyses. The final sample consisted of 312 persons.

Urban-rural areas were defined following the new urban-rural typology proposed by the statistical office of the European Union ${ }^{18}$. That is, urban areas are those with a population density over 300 inhabitants per $\mathrm{km}^{2}$ and a minimum size threshold of 5,000 inhabitants. All other areas are identified as rural.

Psychiatric information in the present study included history of mental health service utilization (either specialized mental health care or general practitioner visits for psychiatric reasons), psychopathology, suicide attempts, and psychiatric hospitalization. Additionally, we obtained information on general practitioner visits for non-psychiatric account for overall health status other than mental disorders. This information was gathered for each individual through hospital databases. Medical information in XXXX (blinded) is centralized, so healthcare records of patients across the whole province could be accessed. Eight individuals had no medical history despite they appeared in the centralized hospital database, so these patients were excluded from analyses using clinical variables.

Census and all-cause mortality data in the province of XXXX (blinded) was obtained from the Spanish Statistical Office. Spain has a population of 46,624,382 and is divided into 50 provinces. XXXX (blinded) is a province located in the East Coast of Spain. XXXX (blinded) has a population of 582,327 and is ranked 25 out of 50 as per number of residents in Spain.

Similar to Spain, which has a population density of 92.5 people/km2, the population density of XXXX (blinded) (87.8 people/km2) is lower than the European average of 
$116.7^{18,19}$. In fact, population in XXXX (blinded) is fairly segregated (i.e., it has 105 towns with less than 2000 residents, 19 towns with between 2000 and 10000 residents, and only 11 towns with more than 10000 residents) and does not have a metropolis. The largest urban city, XXXX (blinded), has less than 173,000 residents and has no metro ${ }^{19}$. Another distinctive characteristic of the province is that its largest cities (i.e., most urban) tend to be located in the coast, while smallest towns (i.e., most rural) are mainly inland. This demographic distribution may have implications for the impact of rurality on suicide.

Suicide methods were classified following ICD-10 recommendations ${ }^{20}$, including both intentional or unintentional codes: self-poisoning by solids, liquids, or gas (ICD10 X6069, Y10-Y19); hanging, strangulation, and suffocation (X70, Y20); drowning and submersion (X71, Y21); firearm (X72-X74, Y22-Y24); smoke, fire, and flames (X76, Y26); sharp object (X78, Y28); jumping from a high place (X80, Y30); jumping or lying before moving object (X81, Y31); and other specified means (electrocution; X83, Y33). Table 1 shows the frequency of each suicide method. Infrequent suicide methods $(<5 \%$ of the total) were collapsed into an "other" category for data analytic reasons. These included smoke, fire, and flames, sharp object, drowning and submersion, jumping or lying before moving object, and other specified means (electrocution).

\section{INSERT TABLE 1 APPROXIMATELY HERE}

Data analysis

First, we calculated suicide rates in the province of XXXX (blinded) from 2009 to 2015 across each population area. We created yearly mortality ratios using the official census of XXXX (blinded). 
Then we investigated whether there were urban-rural differences in study variables by means of a Chi-square test. These included age, sex, suicide method, mental health service utilization, history of psychopathology, suicide attempts, and psychiatric hospitalization. Analyses were performed for both sexes and all ages together, separated for males and females, and split by age. Following past research ${ }^{11}$, age groups were young (15-34 years), middle (35-64 years), and old age ( $\geq 65$ years).

Whenever the Chi-square test revealed a significant difference between observed and expected counts between two or more cells, we used the adjusted standardized residual as a post hoc test to determine the origin of the difference. Residuals represent the difference between observed and expected counts in a cell. Larger residuals indicate a greater contribution of a cell to the Chi-square vale. A cut-off score of 1.96 is often used as an indicator that a cell contributed to the significance of the Chi-square test. For the previous, we aggregated suicide data across all study period.

Results

Suicide ratios as a function of rurality level: analyses by sex and age

The number of suicides in rural and urban areas from 2009 to 2015 were 113 (36.2\%) and $199(63.8 \%)$, respectively. Table 2 shows yearly average suicide ratios for the whole sample and separated by sex and age. Following past research ${ }^{9}$, we used the median year (i.e., 2012) as the reference population and we included residents aged 15 and over.

Taking the whole sample, suicide ratios were highest in rural areas (9.96 suicides per 100,000 residents). When split by sex and age, most of the difference in favor of higher suicide rates in rural areas occurred in males and adults aged over 65 years. 


\section{INSERT TABLE 2 APPROXIMATELY HERE}

Sociodemographic and psychiatric differences in suicide across rurality levels: whole sample

As seen in Table 3, the Chi-square test indicated urban-rural differences suicide method when including both sexes and all ages. A post hoc analysis for suicide methods revealed that self-poisoning was a common suicide method in urban areas (adjusted standardized residual $=2.1$ ), but it was less frequently used by rural residents (adjusted standardized residual $=-2.1$ ). The use of firearm was marginally more frequent in rural areas (adjusted standardized residual $=1.9$ ) and relatively rare in urban areas (adjusted standardized residual $=-1.9)$. The difference in specialized mental health service use was almost significant, in favor of urban areas $\left(\chi^{2}=3.82, p=.051\right.$; adjusted standardized residual for urban and rural cells $=2.0$ and -2.0 , respectively).

We did not find urban-rural differences in sex, age, mental disorders, mental health service utilization in the last year (either treated by a psychiatrist or a general practitioner), history of suicide attempt, and history of psychiatric hospitalization.

Differences in country of birth could not be performed as only 3 individuals (all of them in urban areas) were not born in Spain.

\section{INSERT TABLE 3 APPROXIMATELY HERE}

Sociodemographic and psychiatric differences in suicide across rurality levels: split by $\operatorname{sex}$

In addition to urban-rural differences with both sexes, we performed a separate analysis for males and females (Table 4). With regards to males, results revealed urban-rural differences in specialized mental health service use and suicide method. Specifically, 
the proportion of individuals with history of visits to a specialized mental health service was larger in urban areas (adjusted standardized residual $=2.0$ ) compared to their rural counterparts (adjusted standardized residual $=-2.0$ ). Taking suicide methods, hanging and firearms were frequent in rural areas (adjusted standardized residuals $=2.2$ and 2.0, respectively) and infrequent in urban areas (adjusted standardized residuals $=-2.2$ and 2.0, respectively). Conversely, poisoning was rare in rural areas bur frequent in urban areas (adjusted standardized residuals $=-2.9$ and 2.9, respectively). We did not find differences in age and psychiatric variables in males.

Considering females, our analyses indicated urban-rural differences in age and prevalence of substance use disorders. That is, the number of suicides committed by older females ( $\geq 65$ years) was larger than expected in rural (adjusted standardized residuals $=2.5$ ) compared to urban areas (adjusted standardized residual $=-2.5$ ). In relation to mental disorders, substance use was more frequent in urban than in rural areas (adjusted standardized residuals $=2.4$ and -2.4 , respectively). We did not find urban-rural differences in the remaining psychiatric variables and suicide method in females.

\section{INSERT TABLE 4 APPROXIMATELY HERE}

Sociodemographic and psychiatric differences in suicide across rurality levels: split by age

We also calculated urban-rural differences in sociodemographic and psychiatric factors as a function of age (Table 5). We did not find urban-rural differences in sociodemographic and psychiatric variables in individuals aged 15-64 years. With regards to older individuals, we found urban-rural differences in the proportion of 
patients with GP visit for psychiatric reasons in the last year in favor of rural areas (adjusted standardized residual for urban and rural areas was -2.2 and 2.2, respectively).

\section{INSERT TABLE 5 APPROXIMATELY HERE}

\section{Discussion}

The present study aimed at comparing rural-urban differences in suicidality in XXXX (blinded) with those reported in other countries. Also, urban-rural differences in sociodemographic and psychiatric factors were explored in order to better understand urban-rural differences in suicide. Consistent with past findings, we found higher suicide rates in rural areas, especially for men and older people 5,6,21. Additionally, urban-rural differences in sociodemographic and psychiatric variables were obtained. Most interestingly, these differences were sensitive to sex and age, in line with existent $\operatorname{research}^{9,11}$.

Overall and urbanity-adjusted suicide rates in the present study are consistent with previous findings. For instance, male suicide was three times more frequent than female's and suicide rates increased with age, especially in people over 65 years ${ }^{22}$. Also, rural-urban suicide rates were comparable with those reported in the USA for both sexes ${ }^{5,6}$. Interestingly, these studies also revealed that urban-rural trends in suicide have shifted in the last decades. A similar finding was obtained in the present investigation. In Spain, suicide rates were also highest in urban areas in $1991^{23}$. However, our results indicate that urban-rural suicide patterns have changed.

The inclusion of a large set of potential predictors of urban-rural differences is one of the strengths of the present investigation. Also, the use of the recently developed urbanrural typology proposed by the statistical office of the European Union is novel to research ${ }^{18}$. Urban-rural differences in suicide rates have been repeatedly investigated 
5,6,8,10. However, attempts to explain urban-rural differences in suicide including a wide range of candidates, as in the current study, are scarce ${ }^{11}$. In line with the study of Taylor et al., one of the findings in the present investigation was that factors that contribute to urban-rural differences in suicide might differ for men and women. Some similarities can be observed when comparing the two investigations. For instance, both studies suggest that specialized mental health service use and accessibility to suicide methods (i.e., firearms) are important factors associated with urban-rural differences in suicide, while the effect of other psychiatric factors like mental disorders or history of suicide attempts appears to be negligible. However, as opposed to the study of Taylor et al., in our investigation the aforementioned differences were only revealed for men. More research is needed to consolidate these findings.

In addition to sex, we also explored urban-rural differences in psychiatric factors across age groups. Our results revealed a greater proportion of rural individuals with a 1-year prevalence of visits with their general practitioners for psychiatric reasons, but only in the older age group. Interestingly, though, we did not find a higher prevalence of lifetime mental problems in rural older individuals. Further analyses revealed that urban-rural differences in GP visits in older adults were attributable to a duplication of services in rural areas. In Spain, mental problems can be treated by general practitioners, psychiatrists, or both. In our study, all rural older individuals attending a psychiatrist (i.e., specialized mental health service) were also in contact with their GP. In contrast, in urban areas, only $50 \%$ of older patients received mental health treatment by both professionals. Despite this is remains speculative, it is possible that cultural (i.e., trust in the GP) or accessibility reasons (i.e., distance to a specialized mental health facilities) help explain these differences. Our results also indicate that these differences are likely to disappear with new generations or, at least, with younger age. 
Ultimately, the present study findings might serve guide suicide Spanish prevention strategies, especially in XXXX (blinded). For example, suicide method, which we found to be sensitive to rurality, has been said to reflect the strength of intention to die, with firearms being the most lethal suicide method (Shenassa, Catlin, \& Buka, 2003). Consequently, rural males should be considered a high-risk group for suicide due to the lethality of their preferred suicide methods, so prevention efforts should be strongest in this population. Past research has revealed that legislation on suicide means might be an effective way of doing this ${ }^{24,25}$. In the light of our results, legislation tackling accessibility to firearms in rural areas might also be a recommendable practice in XXXX (blinded), especially in men. In addition to the differences in suicide methods, our study revealed urban-rural differences in mental health service utilization but not in the prevalence of mental health disorders. This is important because psychiatric problems are amongst the most important risk factors for suicide ${ }^{26}$. However, in the present study urban-rural differences in suicide were not attributable to differences in the prevalence of mental health problems, which were comparable across rurality levels, but to the fact that rural men were less likely to attend to a specialized mental health institution. In our opinion, these differences in mental health service use are likely to be due to cultural reasons (i.e., stigma that goes with attending a specialized mental health facility) that are strongest in rural men. If accessibility to mental health facilities was the problem, differences should have occurred for women as well. Suicide prevention plans should tap into the aforementioned differences in mental health service use in rural men. The present study certainly has some limitations. For example, while the focus on a small geographical area facilitated the collection of numerous psychiatric factors, it limited our analyses and the generalizability of the results. Specifically, a Poisson regression could not be performed due to the reduced number of counts when including 
different strata (i.e., urban-rural, age groups, sex, and psychiatric factors). Also, hospital databases did not include some relevant information for understanding suicide, such as civil status, number of persons living together, or socioeconomic status.

Despite the previous shortcomings, results in the present investigation might shed new light into research on urban-rural differences in suicide. First, because it is the first study that explored rural-urban differences in suicide in Spain. Cross-national replication of findings is important to develop theories explaining the impact of rurality on suicide. Second, because we investigated urban-rural differences in a large set of psychiatric factors, which might help understand to which extent psychiatric variables account for urban-rural differences in suicide. Most importantly, we performed separate analyses by sex and age, and concluded that factors explaining rural-urban differences in suicide might be different for men and women and across age groups. 


\section{References}

1. Sáiz PA. Prevención del suicidio en España: una necesidad clínica no resuelta Suicide prevention in Spain : An uncovered clinical need. Rev Psiquiatr Salud Ment 2014;7:1-4.

2. Iglesias-García C, Sáiz PA, Burón P, Sánchez-Lasheras F., Jiménez-Treviño L.,

Fernández-Artamendi S., et al. Suicidio, desempleo y recesión económica en España. Rev Psiquiatr Salud Ment 2017:4-11.

3. World Health Organization. Preventing suicide. A global imperative. Geneva, Switzerland; 2014:89.

4. Spanish Statistital Office. Deaths according to cause of death. 2016.

5. Singh GK, Siahpush M. Increasing rural-urban gradients in US suicide mortality, 1970-1997. Am J Public Health 2002;92:1161-1167.

6. Fontanella CA, Hiance-Steelesmith DL, Phillips GS, Bridge JA, Lester N, Sweeney HA, et al. Widening Rural-Urban Disparities in Youth Suicides, United States, 19962010. JAMA Pediatr 2015;169:466.

7. Middleton N, Gunnell D, Frankel S, Whitley E., Dorling D. Urban-rural differences in suicide trends in young adults: England and Wales, 1981-1998. Soc Sci Med 2003;57:1183-1194.

8. Razvodovsky Y, Stickley A. Suicide in urban and rural regions of Belarus, 19902005. Public Health 2009;123:27-31.

9. Levin KA, Leyland AH. Urban/rural inequalities in suicide in Scotland, 1981-1999. Soc Sci Med 2005;60:2877-2890. 
10. Choi KH, Kim DH. Trend of suicide rates according to urbanity among adolescents by gender and suicide method in Korea, 1997-2012. Int J Environ Res Public Health 2015;12:5129-5142.

11. Taylor R, Page A, Morrell S, Harrison J, Carter G. Social and psychiatric influences on urban-rural differentials in Australian suicide. Suicide Life Threat Behav 2005;35:277-290.

12. Morrell S, Taylor R, Slaytor E, Ford P. Urban and rural suicide differentials in migrants and the Australian-born, New South Wales, Australia 1985-1994. Soc Sci Med 1999;49:81-91.

13. Kessler RC, McGonagle KA, Zhao S, Nelson CB, Hughes M, Eshleman S, et al.. Lifetime and 12-month prevalence of DSM-III-R psychiatric disorders in the United States. Results from the National Comorbidity Survey. Arch Gen Psychiatry 1994;51:819.

14. Judd FK, Jackson HJ, Komiti A, Murray G, Hodgins G, Fraser C. High prevalence disorders in urban and rural communities. Aust N Z J Psychiatry 2002;36:104-113.

15. Martin RM, Sterne JAC. Social and economic variation in general practice consultation rates amongst men aged 16-39. Heal Stat Q 2001;9:29-36.

16. Yip PSF, Callanan C, Yuen HP. Urban/rural and gender differentials in suicide rates: East and West. J Affect Disord 2000;57:99-106.

17. Giner L, Guija JA. Número de suicidios en España: diferencias entre los datos del Instituto Nacional de Estadística y los aportados por los Institutos de Medicina Legal. Rev Psiquiatr Salud Ment 2014;7:139-146.

18. Eurostat. Population density. 2014. 
19. XXXX (blinded). Demography. XXXX (blinded). 2014.

20. World Health Organization. ICD-10 International Statistical Classification of Diseases and Related Health Problems 10th Revision. 2016.

21. Mehlum L, Hytten K, Gjertsen F. Epidemiological trends of youth suicide in Norway. Arch Suicide Res 1999;5:193-205.

22. Zacharakis CA, Madianos MG, Papadimitriou GN, Stefanis CN. Suicide in Greece 1980-1995: Patterns and social factors. Soc Psychiatry Psychiatr Epidemiol $1998 ; 33: 471-476$.

23. Ruiz-Pérez I, de Labry Olry. El suicidio en la España de hoy. Gac Sanit 2006;20:25.

24. Daigle MS. Suicide prevention through means restriction: Assessing the risk of substitution. Accid Anal Prev 2005;37:625-632.

25. Yip PSF, Caine E, Yousuf S, Chang SS, Wu KCC, Chen YY, et al. Means restriction for suicide prevention. Lancet 2012;379:2393-2399.

26. Gómez-Durán EL, Forti-Buratti MA, Gutiérrez-López B, Belmonte-Ibáñez A, Martin-Fumadó C. Trastornos psiquiátricos en los casos de suicidio consumado en un área hospitalaria entre 2007-2010. Rev Psiquiatr Salud Ment 2016;9:31-38. 
Table 1. Frequency of suicide methods across study duration (2009-2015)

\begin{tabular}{|l|l|}
\hline Suicide method & Frequency (\%) \\
\hline Self-poisoning by solids, liquids, or gas & $50(14.5 \%)$ \\
\hline Hanging, strangulation, and suffocation & $162(46.8 \%)$ \\
\hline Firearm & $25(7.2 \%)$ \\
\hline Jumping from a high place & $80(23.1 \%)$ \\
\hline Other methods & $29(8.4 \%)$ \\
\hline Smoke, fire, and flames & $1(0.3 \%)$ \\
\hline Sharp object & $3(0.9 \%)$ \\
\hline Drowning and submersion & $9(2.6 \%)$ \\
\hline Jumping or lying before moving object & $15(4.3 \%)$ \\
\hline Other specified means (electrocution) & $1(0.3 \%)$ \\
\hline & \\
\hline & \\
\hline & \\
\hline & \\
\hline & \\
\hline & \\
\hline & \\
\hline & \\
\hline
\end{tabular}


Table 2. Urban-rural suicide ratio for every 100,000 residents over 15 years considering official census data in the province of XXXX (blinded) in 2012

\begin{tabular}{|c|c|c|c|c|c|c|}
\hline & \multicolumn{2}{|c|}{$\begin{array}{l}\text { Population over } 15 \\
\text { years in } 2012^{1}\end{array}$} & \multicolumn{2}{|c|}{$\begin{array}{l}\text { Yearly average number of } \\
\text { suicides from } 2009 \text { to } 2015 \\
2\end{array}$} & \multicolumn{2}{|c|}{$\begin{array}{l}\text { Yearly suicide ratio (per 100,000 } \\
\text { residents over } 15 \text { years) }\end{array}$} \\
\hline & urban & rural & urban & rural & urban & rural \\
\hline Both sexes. All ages & 349,906 & 162,131 & 28.43 & 16.14 & 8.13 & 9.96 \\
\hline Male. All ages & 173,037 & 82,467 & 21.43 & 12.71 & 12.38 & 15.41 \\
\hline Female. All ages & 176,869 & 79,664 & 7.00 & 3.43 & 3.96 & 4.31 \\
\hline Both sexes. $15-34$ years & 109,038 & 45,555 & 3.86 & 1.86 & 3.54 & 4.08 \\
\hline Both sexes. 35-64 years & 178,582 & 78,194 & 16.00 & 7.43 & 8.96 & 9.50 \\
\hline Both sexes. $\geq 65$ years & 62,286 & 38,382 & 8.56 & 6.86 & 13.74 & 17.87 \\
\hline
\end{tabular}

Note: urban = population density $>300$ inhabitants $/ \mathrm{km}^{2}$ and size $>5,000$ inhabitants; rural $=$ all other. 
Yearly suicide ratios were calculated by dividing yearly average number of suicides in a cell by the number of residents corresponding to the same cell according to 2012 census. For example, to obtain female suicide ratio in rural areas, we divided 3.43 by 79,664 . Then, results were multiplied by 100,000 to obtain a suicide ratio per 100,000 residents.

${ }^{1}$ Source: Spanish Statistical Office

${ }^{2}$ Source: Institute of Forensic Medicine 
Table 3. Urban-rural differences in sociodemographic and psychiatric factors (whole sample)

\begin{tabular}{|c|c|c|c|c|}
\hline & Urban $(\%)$ & Rural (\%) & $\chi^{2}$ & $p$ \\
\hline Males & 75.4 & 78.8 & 0.46 & .497 \\
\hline Age & & & 4.85 & .089 \\
\hline $15-34$ & 13.6 & 11.5 & & \\
\hline $35-64$ & 56.3 & 46.0 & & \\
\hline$\geq 65$ & 30.2 & 42.5 & & \\
\hline Mental disorder $(I C D-9)^{a}$ & 63.8 & 67.3 & 0.50 & .479 \\
\hline Affective disorder & 41.5 & 44.9 & 0.33 & .567 \\
\hline Anxiety disorder & 58.5 & 59.8 & 0.05 & .831 \\
\hline Psychotic disorder & 14.0 & 11.2 & 0.47 & .494 \\
\hline Substance use disorder & 21.8 & 18.7 & 0.40 & .529 \\
\hline Specialized mental health service use ${ }^{a}$ & $34.2 *$ & $23.4^{*}$ & 3.82 & .051 \\
\hline GP visit (psychiatric reasons) $^{a}$ & 53.4 & 62.6 & 2.40 & .121 \\
\hline GP visits (non-psychiatric reasons) $^{a}$ & 53.9 & 63.6 & 2.63 & .105 \\
\hline Suicide attempt ${ }^{b}$ & 24.9 & 18.7 & 1.50 & .221 \\
\hline Psychiatric hospitalization $^{b}$ & 19.7 & 14.0 & 1.52 & .217 \\
\hline Suicide method & & & 10.31 & .036 \\
\hline
\end{tabular}




\begin{tabular}{|l|l|l|l|l|}
\hline Self-poisoning & $18.6^{*}$ & $9.7^{*}$ & & \\
\hline Hanging & 53.1 & 42.7 & & \\
\hline Firearm & 5.0 & 10.6 & & \\
\hline Jumping & 25.6 & 22.1 & & \\
\hline Other & 8.0 & 4.4 & & \\
\hline
\end{tabular}

Other suicide methods include: smoke, fire, and flames, sharp object, drowning and submersion, jumping or lying before moving object, and electrocution.

${ }^{a} 1$ year prevalence

${ }^{\mathrm{b}}$ Lifetime prevalence

* Cell significantly contributes to Chi-square significance (adjusted standardized residual is greater than 1.96 or smaller than -1.96 ) 
Table 4. Urban-rural differences in sociodemographic and psychiatric factors (separated by sex)

\begin{tabular}{|c|c|c|c|c|c|c|c|c|}
\hline & \multicolumn{4}{|l|}{ Male } & \multicolumn{4}{|c|}{ Female } \\
\hline & $\begin{array}{l}\text { Urban } \\
(\%)\end{array}$ & $\begin{array}{l}\text { Rural } \\
(\%)\end{array}$ & $\chi^{2}$ & $p$ & $\begin{array}{l}\text { Urban } \\
(\%)\end{array}$ & $\begin{array}{l}\text { Rural } \\
(\%)\end{array}$ & $\chi^{2}$ & $p$ \\
\hline Age & & & 1.57 & .456 & & & 6.45 & .040 \\
\hline $15-34$ & 13.3 & 13.5 & & & 14.3 & 4.2 & & \\
\hline $35-64$ & 56.0 & 48.3 & & & 57.1 & 37.5 & & \\
\hline$\geq 65$ & 30.7 & 38.2 & & & $28.6^{*}$ & $58.3^{*}$ & & \\
\hline Mental disorder $(I C D-9)^{a}$ & 57.5 & 61.4 & 0.34 & .563 & 80.9 & 87.5 & 0.50 & .479 \\
\hline Affective disorder & 34.2 & 33.7 & 0.01 & .937 & 63.8 & 83.3 & 2.90 & .089 \\
\hline Anxiety disorder & 52.7 & 54.2 & 0.05 & .829 & 76.6 & 79.2 & 0.06 & .806 \\
\hline Psychotic disorder & 15.8 & 12.0 & 0.59 & .443 & 8.5 & 8.3 & $<0.01$ & .980 \\
\hline Substance use disorder & 19.9 & 22.9 & 0.29 & .588 & $27.7 *$ & $4.2 *$ & 5.54 & .019 \\
\hline $\begin{array}{l}\text { Specialized mental health } \\
\text { service use }^{a}\end{array}$ & $31.5^{*}$ & $19.3 *$ & 4.01 & .045 & 42.6 & 37.5 & 0.17 & .682 \\
\hline $\begin{array}{l}\text { GP visit (psychiatric } \\
\text { reasons })^{a}\end{array}$ & 47.3 & 56.6 & 1.86 & .173 & 72.3 & 83.3 & 1.05 & .305 \\
\hline $\begin{array}{l}\text { GP visits (non-psychiatric } \\
\text { reasons })^{a}\end{array}$ & 52.7 & 61.4 & 1.63 & .202 & 57.4 & 70.8 & 1.21 & .272 \\
\hline Suicide attempt ${ }^{b}$ & 19.2 & 12.0 & 1.94 & .163 & 42.6 & 41.7 & 0.01 & .943 \\
\hline $\begin{array}{ll}\text { Mental } & \text { health } \\
\text { hospitalization }^{b} & \end{array}$ & 19.2 & 10.8 & 2.71 & .099 & 21.3 & 25.0 & 0.13 & .722 \\
\hline Suicide method & & & 15.8 & .003 & & & 3.72 & .446 \\
\hline
\end{tabular}




\begin{tabular}{|l|l|l|l|l|l|l|l|l|} 
& & & 6 & & & & & \\
\hline Self-poisoning & $13.3^{*}$ & $2.2^{*}$ & & & 34.7 & 37.5 & & \\
\hline Hanging & $48.0^{*}$ & $62.9^{*}$ & & & 26.5 & 16.7 & & \\
\hline Firearm & $6.0^{*}$ & $13.5^{*}$ & & & 2.0 & 0.0 & & \\
\hline Jumping & 24.0 & 15.7 & & & 30.6 & 45.8 & & \\
\hline Other & 8.7 & 5.6 & & & 6.1 & 0.0 & & \\
\hline
\end{tabular}

Other suicide methods include: smoke, fire, and flames, sharp object, drowning and submersion, jumping or lying before moving object, and electrocution.

${ }^{a} 1$ year prevalence

${ }^{\mathrm{b}}$ Lifetime prevalence

* Cell significantly contributes to Chi-square significance (adjusted standardized residual is greater than 1.96 or smaller than -1.96 ) 
Table 5. Urban-rural differences in sociodemographic and psychiatric factors (separated by age)

\begin{tabular}{|c|c|c|c|c|c|c|c|c|c|c|c|c|}
\hline & \multicolumn{4}{|l|}{$15-34$} & \multicolumn{4}{|l|}{$35-64$} & \multicolumn{4}{|l|}{$\geq 65$} \\
\hline Males & 74.1 & 92.3 & 1.82 & .177 & 75.0 & 82.7 & 1.20 & .273 & 76.7 & 70.8 & 0.47 & .492 \\
\hline Affective disorder & 33.3 & 25.0 & 0.27 & .603 & 46.7 & 43.8 & 0.12 & .731 & 35.6 & 51.1 & 2.56 & .109 \\
\hline Anxiety disorder & 55.6 & 41.7 & 0.64 & .423 & 61.7 & 66.7 & 0.35 & .552 & 54.2 & 57.4 & 0.11 & .741 \\
\hline Psychotic disorder & 18.5 & 25.0 & 0.21 & .644 & 16.8 & 10.4 & 1.08 & .300 & 6.8 & 8.5 & 0.11 & .737 \\
\hline$G P$ visit (psychiatric reasons) ${ }^{a}$ & 44.4 & 33.3 & 0.42 & .515 & 57.9 & 62.5 & 0.29 & .593 & $49.2^{*}$ & $70.2 *$ & 4.78 & .029 \\
\hline GP visits (non-psychiatric reasons) ${ }^{a}$ & 25.9 & 8.3 & 1.58 & .209 & 40.2 & 52.1 & 1.90 & .168 & 91.5 & 89.4 & 0.14 & .705 \\
\hline Suicide attempt ${ }^{b}$ & 33.3 & 33.3 & $<0.01$ & $>.999$ & 27.1 & 18.8 & 1.25 & .264 & 16.9 & 14.9 & 0.08 & .774 \\
\hline
\end{tabular}




\begin{tabular}{|l|l|l|l|l|l|l|l|l|l|l|l|l|} 
Mental health hospitalization $^{b}$ & 29.6 & 33.3 & 0.05 & .817 & 26.2 & 12.5 & 3.62 & .057 & 3.4 & 10.6 & 2.23 & .135 \\
\hline Suicide method & & & 2.13 & .546 & & & & & & \\
\hline Self-poisoning & 11.1 & 0.0 & & & 22.3 & 5.8 & 8.75 & .068 & 15.0 & 16.7 & \\
\hline Hanging & 37.0 & 53.8 & & & 44.6 & 59.6 & & & 41.7 & 45.8 & & \\
\hline Firearm & 0.0 & 0.0 & & & 7.1 & 11.5 & & & 3.3 & 12.5 & & \\
\hline Jumping & 37.0 & 30.8 & & & 18.8 & 19.2 & & & 33.3 & 22.9 & & \\
\hline Other & 14.8 & 15.4 & & & 7.1 & 3.8 & & & 6.7 & 2.1 & & \\
\hline
\end{tabular}

Other suicide methods include: smoke, fire, and flames, sharp object, drowning and submersion, jumping or lying before moving object, and electrocution.

${ }^{a} 1$ year prevalence

${ }^{\mathrm{b}}$ Lifetime prevalence

* Cell significantly contributes to Chi-square significance (adjusted standardized residual is greater than 1.96 or smaller than -1.96) 
